\title{
PROPOSTA DE UM MODELO DE APLICAÇÃO DO MÉTODO QFD NO PROCESSO DE AUTOAVALIAÇÃO NAS INSTITUIÇÕES DE ENSINO SUPERIOR
}

\section{Jair Gustavo de Mello Torres'}

\begin{abstract}
Resumo: O presente artigo discute a qualidade no ensino superior, enfatizando sua importância e necessidade, especialmente em programas de graduação, e o papel da avaliação institucional neste processo. Apresenta-se ainda, a discussão de uma proposta de modelo de aplicação do método QFD no processo de autoavaliação de IES, procurando atender as diretrizes do Sistema Nacional de Avaliação da Educação Superior - SINAES no Brasil. O QFD foi adotado para que se pudesse estabelecer o desenvolvimento de uma proposta de planejamento da qualidade, com o objetivo de promover a melhoria dos serviços praticados das instituições de ensino superior. Destacam-se ainda da literatura, alguns exemplos práticos de uso do QFD no âmbito educacional, enfatizando sua aplicabilidade neste setor, como os demais benefícios para as instituições.
\end{abstract}

Palavras-chave: QFD; Qualidade; Gestão Educacional; SINAES.

\footnotetext{
1 Senac São Paulo/Brasil. E-mail: jair_gustavo@yahoo.com.br.
} 